\title{
Phytoremediation Enhancement of Kenaf Plant (Hibiscus cannabinus L.) Grown on Spent Oil Polluted Soil
}

\author{
Olajumoke Oke Fayinminnu \\ Department of Crop Protection and Environmental Biology, Faculty of Agriculture, \\ University of Ibadan, Nigeria
}

Tel: 234-802-346-0950Ｅ-mail: olorijkb2008@gmail.com

Received: December 19, 2019 Accepted: March 5, 2020 Published: March 10, 2020

doi:10.5296/jee.v11i1.16640ＵRL: https://doi.org/10.5296/jee.v11i1.16640

\begin{abstract}
Oil pollution especially Spent Lubricating Oil is a wide environmental problem in Nigeria. It constitutes potential toxic effects on soil, flora, fauna and humans and also making the environment unsightly. This study assessed the potential of kenaf plant as a phytoremediator grown in spent oil polluted soil for a period of 84 days (12 weeks). Pot experiment was conducted in the Nursery site of the Moist Forest Research Station, Forestry Research Institute of Nigeria (FRIN), Ibadan, Oyo State, Nigeria. The treatments: amended (with organic manure) and unamended (without organic manure) soils and three pollution levels ( 0 , 3 and 6\%) of spent engine oil, each filled in eight-liter plastic pots with $6 \mathrm{~kg}$ soil. Growth parameters: plant height, stem diameter and number of leaves were collected and Total Petroleum Hydrocarbon (TPH) in soil was determined. Data were analyzed using descriptive statistics and ANOVA. Results at 12 weeks (84 days) showed amended (control 0\%) treatment having highest plant height $(112.17 \mathrm{~cm})$, stem diameter $(8.92 \mathrm{~cm})$ and number of leaves (178.43), while 6\% unamended level of pollution had the lowest plant height $(26.78$ $\mathrm{cm})$, stem height $(1.62 \mathrm{~cm})$ and number of leaves (8.06). Amended soil had the highest total percentage reduction of TPH $(75.90,90.05$ and 90.30\%), when compared with unamended soil with lowest values $(76.88,85.18$ and $82.36 \%$ ) at 0,3 and 6 pollution levels, respectively. Reduction of TPH in the phytoremediation process was in this order of pollution levels $6 \%>$ $3 \%>0 \%$. This study revealed effectiveness of kenaf with organic amendment in remediating Total Petroleum Hydrocarbon in oil polluted soil, hence a good potential phytoremediator.
\end{abstract}

Keywords: Kenaf, amended and unamended soils, Pollution levels, Total petroleum hydrocarbon 


\section{Introduction}

Petroleum oil keeps the factors of the industrialized countries working and provides the revenues in our daily life in which we depend on. However, its impact on the environment and toxic effects either received scant attention or were simply ignored (Science in Africa, 2002) and not considered. Pollution problems are global concern especially in Africa which continue increasing in the environment with toxic effects on the public; due to the exploration and its activities in the petrol chemical products business. This is because of misuse / handlings, accidental spillage, effluent and waste discharges and improper disposal of these products (Science in Africa, 2002).

In Nigeria, the number of oil spills occurring in the Niger Delta (an area of 20,000 square kilometers (12,000 square miles)) is really disturbing. Such spills can be caused by accidents, corrosion, or poor maintenance; also, an analysis of 550 oil spills within one year and 394 spills in smaller areas have been reported in Niger Delta (The Nation Newspaper, 2015). The National Oil Spill Detection and Response Agency (NOSDRA) of Nigeria reported that over 9343 spills occurred between 2006-2015 (Balogun \& Raji, 2016). As the spill occurs, it spreads onto farmlands and water bodies; these materials are dispersed and sink and may kill local bottom living plants and animals by burying them (Oil of Poverty in the Niger Delta, 2004). Mangrove forests are being obliterated, fish and shellfish are dying off and the whole ecosystems are collapsing (The Nation Newspaper, 2015).

Pollution toxicity from Spent Lubricating Oil (SLO) or spent engine oil is an environmental problem which is more widespread than crude oil pollution (Odjegba \& Sadiq, 2002). This is because SLO from automobiles, generators and other machines is indiscriminately dumped into the environment across the length and breadth of the country. Disposal of spent engine oil seeps into the grounds and is taken up by the roots of plants which has been persistently problematic, (Nwoko et al., 2007; Adenipekun et al., 2008) causing lower soil fertility, poor growth such as plant height, number of leaves and high reduction in yield of crops (Fayinminnu \& Abimbola, 2016). This is as a result of large amounts of highly toxic hydrocarbons (Polyhydrocarbons (PHCs)) retained in the soil (Haung et al., 2004; Vwioko \& Fashemi, 2005; Fayinminnu \& Abimbola, 2016). The SLO contains chemical additives including amines, phenols and benzene which are dangerous to living organisms (Meinz, 1999). All these pollutants would have spread to large areas and contaminating soils, water, diminishing air and water quality and thereby endangering aquatic and terrestrial environment (USEPA, 2007; Ebere et al., 2011) hence threatening public health, food quality and safety. Pollution of any level has a deleterious effect upon the entire ecosystem and destroying habitats and food (Amakiri \& Onofegbara, 1983; USEPA, 2007).

Phytoremediation is a plant-based technology that uses plants to reduce, remove, degrade or immobilize environmental toxins with the aim of restoring a site to a condition useable for private or public applications (Peer et al., 2006). This method looks attractive when compared with conventional methods due to its intact biological active soil and being not invasive (Wenzel, 2009). Other advantages of phytoremediation on contaminated soil are; an environmentally friendly, cost effective and cleanup of toxic pollutants in the environment 
(Dowling \& Doty, 2009). Several species of plants have been shown to have ability to grow on oil contaminated soils. Among the plants used include; Alfalfa (Medicago sativa L.), horse radish, Mirabilis jalapa L. Carex stricta, Panicum virgatum, Tripsacum dactyloides Eichhornia crassipes and Jatropha curca L. They were found to significantly reduce Total petroleum hydrocarbons (TPHs) (Karthikeyan et al., 1999; Peng et al., 2009; Euliss et al., 2008; \& Idowu \& Fayinminnu, 2016).

Kenaf (Hibiscus cannabinus L.), is a warm-season annual herbaceous, indigenous to West Africa (Science in Africa, 2002; Berti et al., 2013). This plant is usually grown in the Middle Belt of Nigeria in the following states: Kwara, Benue, Niger, Kaduna, Plateau and Nasarawa, also in Sokoto, Borno and Adamawa (far North). People grow kenaf and eat the leaves as vegetables, stem to make potash and for making ropes and fences (Balogun et al., 2008). Other uses of kenaf include medicine (Cheng, 2001), food additive (Hosomi, 2000), medium for mushroom cultivation (Cheng, 2001; Liu, 2003) environmental cleaning (Lam, 2000), oil and chemical absorbents (Sameshima, 2000), paper pulp and cordage and promising lignocellulosic feedstock (Berti et al., 2013).

Kenaf fines contain many pores, which will not only absorb the oil, but also allow for less leakage or release of oil and the microorganisms (Borazjani \& Diehl, 1994). The plant is biodegradable, high in protein and contains very large numbers of natural microorganisms and assist in remediation process. Preliminary studies conducted at Mississippi Forest Products Laboratory (MFPL) (1994) showed that kenaf absorbed over 55\% of the oil from contaminated soil. In addition, the leaching potential of kenaf appeared to be low $(0.02 \%)$ from contaminated kenaf (Borazjani \& Diehl, 1994, 2010). Centre for Environmental Resources and Sustainable Ecosystems (CERASE) also used kenaf plant and microorganisms to clean up oil spills from the environment; particularly those affecting farmlands and fishing areas in Ogba/Egbema/Ndoni local council of Rivers State, Nigeria (CERASE, 2002).

Remediating ability of Hibiscus cannabinus of hydrocarbons in oil polluted soil and water has been reported by earlier researchers (Borazjani \& Diehl, 1994, 2010; Spiares et al., 2001; CERASE, 2002; Abioye et al., 2010; Balogun \& Raji, 2016). This study was therefore evaluating the phytotoxicity of spent oil on growth performance of kenaf plant and kenaf"s enhancement as a phytoremediator of highly toxic Total petroleum hydrocarbon (TPH) in Spent Oil polluted soil.

\section{Materials and Methods}

\subsection{Study Area}

The study site and all the methods carried out in this study followed the same procedures as earlier reported according to Idowu and Fayinminnu (2015; 2016). This study was carried out at the Nursery Site of the Moist Forest Research Station, Forestry Research Institute of Nigeria (FRIN) Ibadan on Latitude $6^{\circ} 32^{\prime}$ and Longitude $5^{\circ} 58^{\prime}$ Altitude $99 \mathrm{~m}$, Annual temperature $22-32^{\circ} \mathrm{C}$ and Mean annual rainfall $2078 \mathrm{~mm}$ Oyo State, Nigeria. 


\subsection{Sources and Collection of Sample Materials}

Organic manure (amended) was obtained from MTN Organic fertiliser at Alesinloye market, Ibadan, Oyo State, Nigeria. The unamended soil was obtained from FRIN. Kenaf seeds with accession number NG/00/12/11/070 from Azare, Bauchi State were collected from the gene bank of National Centre for Genetic Resources and Biotechnology (NACGRAB), Moor Plantation, Ibadan, Nigeria

\subsubsection{Soil Sampling, Preparation and Planting}

Top soil samples $(0-15 \mathrm{~cm})$ were collected randomly with a Dutch auger and trowel from the Forest Floor of Acacia Plantation of the Forestry Research Station. The soil was thoroughly mixed and passed through a $2 \mathrm{~mm}$ sieve to remove the non-soil particulate. They were weighed $6 \mathrm{~kg}$ and distributed into plastic pots and allowed to (delete) for one week before application of amendment. Pollution was done at three levels $(0,3$ and $6 \%(\mathrm{w} / \mathrm{w})$ (weight by weight)) of spent oil in $6 \mathrm{~kg}$ top soil and two classes of soil were used based on amendment (amended and unamended soils). In both cases, the soil was thoroughly homogenized. The chemical and physical properties of the soil samples were determined prior to transplanting in the polluted and unpolluted (Idowu \& Fayinminnu, 2015; 2016).

Eight liter plastic pots were filled with $6 \mathrm{~kg}$ soil that passed through $2 \mathrm{~mm}$ sieve. Experimental design was $2 \times 3$ Factorial in a randomised complete block design and replicated three times. The first factor was soil amendments (amended and unamended soil) and the second factor was three levels of spent oil pollution $(0,3$ and $6 \%(\mathrm{w} / \mathrm{w}))$. The soils in the pots were thoroughly mixed for even distribution and watered. Fifteen seeds of kenaf accession NG/00/12/11/070 were sown in each pot of unpolltued soil in the nursery and later thinned to ten seedlings. These raised seedlings of Hibiscus cannabinus were transplanted to the polluted soils at three (3) Weeks After Planting (WAP).

Ten seedlings were used for each level of pollution, translating to 30 seedlings per replicate and a total of 180 seedlings ( 90 seedlings for amended soil and 90 seedlings for unamended soil) for the experimental setup. The pots were filled with topsoil, thoroughly mixed for even distribution of introduced organic manure which was carefully measured and weighed $(10 \%$ $\mathrm{w} / \mathrm{w}$ ) and spent oil contaminants and watered to field capacity and left for three weeks for biodegradation of the microorganisms. Earlier raised seedlings of Hibiscus cannabinus raised (delete) from seeds were transplanted to the polluted and amended soils at 3 WAP.

Based on the setup, the treatment combinations used in this study were:

Unamended $(\mathrm{w} / \mathrm{w})$

$0 \%$ level of contamination $=6 \mathrm{~kg}$ topsoil $+0 \mathrm{~kg}$ spent lubricating oil $\left(\mathrm{UPS}_{0}\right)$

$3 \%$ level of contamination $=6 \mathrm{~kg}$ topsoil $+0.18 \mathrm{~kg}$ of spent lubricating oil $\left(\mathrm{UPS}_{3}\right)$

$6 \%$ level of contamination $=6 \mathrm{~kg}$ topsoil $+0.36 \mathrm{~kg}$ of spent lubricating oil $\left(\mathrm{UPS}_{6}\right)$

Amended (w/w) 
$0 \%$ level of contamination $=6 \mathrm{~kg}$ topsoil $+0 \mathrm{~kg}$ spent lubricating oil $+0.6 \mathrm{~kg}$ Organic Manure $\left(\mathrm{APS}_{0}\right)$

$3 \%$ level of contamination $=6 \mathrm{~kg}$ topsoil $+0.18 \mathrm{~kg}$ of spent lubricating oil $+0.6 \mathrm{~kg}$ Organic Manure (APS 3 )

$6 \%$ level of contamination $=6 \mathrm{~kg}$ topsoil $+0.36 \mathrm{~kg}$ of spent lubricating oil $+0.6 \mathrm{~kg}$ Organic Manure (APS6)

(according to the procedure of Idowu \& Fayinminnu 2015; 2016).

\subsection{Data Collection}

Growth parameters such as plant height, number of leaves and stem diameter were measured using metre rule, visual count and Venier caliper, respectively starting from four weeks after planting (WAP). Five plants from each treatment class (levels of pollution) were randomly selected and measured fortnightly for twelve weeks. Soil from each pot was mixed thoroughly and sub samples were taken in sampling pack to determine the Total Petroleum Hydrocarbon of the soil.

\subsection{Analysis of Soil and Total Petroleum Hydrocarbon (TPH)}

\subsubsection{Soil Physico-Chemical Parameters}

Soil $\mathrm{pH}$ was determined using the method of Hendershot et al. (1993). Ten grams (10 g) of soil sample was weighed into a $50 \mathrm{ml}$ beaker followed by the addition of $10 \mathrm{ml}$ of distilled water. This was stirred manually for 5 minutes and allowed to stand for 30 minutes and $\mathrm{pH}$ was measured using Jenway $3510 \mathrm{pH}$ meter.

Soil Organic Carbon was determined by the method of the Association of Official Analytical Chemists (AOAC, 2005). Ten milliliters (10 ml) of $1 \mathrm{~N} \mathrm{~K}_{2} \mathrm{Cr}_{2} \mathrm{O}_{7}$ were added to a pre-weighed $5 \mathrm{~g}$ of ground soil sample. Twenty milliliters $(20 \mathrm{ml})$ of concentrated $\mathrm{H}_{2} \mathrm{SO}_{4}$ were added and shaken gently to cool. The suspension was made up to approximately $150 \mathrm{ml}$ mark with distilled water in a conical flask. Ten drops of diphenylamine indicator were introduced and the colour turned black. Titration was done with $0.4 \mathrm{~N}$ Ferrous ammonium sulphate. Duplicate blank was also determined from the value of potassium reduced using this formula:

$\% \mathrm{C}=(10.0-0.04) \times 0.04 \times 100 /$ weight of soil taken

Soil organic matter was determined by the method of Association of Official Analytical Chemists (AOAC, 2005) was used (delete) and Organic Matter was calculated by multiplying Organic Carbon with a factor of 1.729.

The total Nitrogen concentration was determined by the Association of Official Analytical Chemist (AOAC, 2005). One gram (1g) of air-dried soil sample was weighed into $100 \mathrm{ml}$ flask and $4 \mathrm{ml}$ of $2.5 \%$ Potassium Permanganate. The flask was left to stand for 5 minutes with periodic shaking. The flask was then boiled slowly for one hour by adding 2-3 boiling chips and $100 \mathrm{mg}$ of Potassium permanganate every 10 minutes within this one hour. The flask was left to cool before adding $2 \mathrm{ml}$ of concentrated $\mathrm{H}_{2} \mathrm{SO}_{4}$ and $7 \mathrm{~g}$ of selenium mixture $1 \mathrm{k}$ Kjedahl 
tablet. The flask was then heated to get a clear sample. The temperature was increased and digestion lasted for 2 hours. After cooling, 3 drops of Hydrogen Peroxide were added to complete oxidation of organic matter. The flask was then transferred for steam distillation.

Exchangeable bases were determined by pouring $25 \mathrm{~g}$ of air-dried soil into a $250 \mathrm{ml}$ beaker. Neutral normal ammonium acetate solution of $50 \mathrm{ml}$ was added to the beaker. This was stirred and left for one hour. The soil was transferred to a Buchner funnel which was fitted with a moist Whatman No. 42 filter paper under gentle suction using one of the plastic squeeze bottles. The leachate was collected in a $500 \mathrm{ml}$ filter flask. Soil was continuously leached slowly with small portions of ammonium acetate until approximately $200 \mathrm{ml}$ leachate was collected. This leachate was used to determine the total exchangeable metallic cations such as $\mathrm{Na}^{2+} \mathrm{K}^{2+} \mathrm{Ca}^{2+}$ and $\mathrm{Mg}^{2+}$. This was expressed in milliequivalents per $100 \mathrm{~g}$ of soil (Meq/100g). The sum of all exchangeable basic cations is equal to total exchangeable bases (IITA, 2002).

\subsubsection{Total Petroleum Hydrocarbon}

Total Petroleum Hydrocarbon (TPH) was determined by the method of Adesodun and Mbagwu (2008). Ten grammes (10 g) of soil were weighed into $50 \mathrm{ml}$ flask and $20 \mathrm{ml}$ Toluene (Analar Grade) was added. After shaking for 30 minutes on an Orbital Shaker, the liquid phase of the extract was measured at 420 nanometre $(\mathrm{nm})$ using DR/4000 spectrophotometer. The Total Petroleum Hydrocarbon (TPH) in the soil was estimated with reference to a standard curve derived from fresh used engine oil diluted with toluene.

\subsection{Data Analysis}

Data collected were analysed using descriptive statistics and Analysis of Variance (ANOVA) at $\mathrm{P}=0.05$. Significant means were separated by Duncan Multiple Range Test (DMRT). Total Petroleum Hydrocarbon degradation was analyzed by means of percentage reduction.

\section{Results}

\subsection{Physico-chemical Parameters of Soil Used for Phytoremediation}

The physico-chemical properties of the soil and organic manure prior to planting were shown in Table 1. The $\mathrm{pH}$ of the soil 6.85 represented a neutral as shown in Table 1. The soil texture was sandy loamy with higher organic matter

\subsection{Effects of Levels of Pollution and Soil Amendment on Growth Parameters of Kenaf Plant (Hibiscus cannabinus)}

\subsubsection{Effects of Levels of Pollution and Soil Amendment on Plant Height of H. cannabinus}

The effects of varied pollution levels and organic amendment on plant height of $H$. cannabinus from the second (2) weeks after transplanting (WAT) to 12 WAT is presented in Table 2 and Figure 1. Result showed no significant differences $(p>0.05)$ in plant height for the soil amendment and 3 levels of pollution at 2 WAT. Significant differences $(p<0.05)$ were however, observed in plant height of the soil amendment and all the levels of pollution from 4 to $12 \mathrm{WAT}$. The lowest value for plant height was $8.90 \mathrm{~cm}$ recorded from the unamended plot 
at 4WAT, while the highest plant height value $(96.36 \mathrm{~cm})$ was recorded from the amended soil at 12WAT. For the pollution levels, the lowest value of plant height $(9.06 \mathrm{~cm})$ was recorded at 4WAT at $6 \%$ pollution level, while the highest plant height $(114.93 \mathrm{~cm})$ was recorded at $12 \mathrm{WAT}$ at $0 \%$ pollution level (Table 2). At the end of the experiment for 12 weeks, soil amended at $0 \%$ pollution (control) recorded the highest mean plant height of $122.19 \mathrm{~cm}$, followed by amended at 3\% pollution having higher value $96.21 \mathrm{~cm}$. The lowest mean value $(26.78 \mathrm{~cm})$ however, was obtained from unamended soil at $6 \%$ pollution (Figure 1).

Table 1. Physico-chemical properties of soil and organic manure prior before pollution

\begin{tabular}{lll}
\hline PARAMETERS $(\%)$ & COMPOST & $\mathrm{NP}_{0}$ \\
\hline $\mathrm{pH}\left(\mathrm{H}_{2} \mathrm{O}\right)$ & 5.78 & 6.85 \\
Sand $(\mathrm{g} / \mathrm{kg})$ & 6.26 & 91.84 \\
Silt $(\mathrm{g} / \mathrm{kg})$ & 0.00 & 4.67 \\
Clay $(\mathrm{g} / \mathrm{kg})$ & 0.00 & 3.49 \\
Organic Carbon $(\mathrm{g} / \mathrm{kg})$ & 36.38 & 0.98 \\
Total N(g/kg) & 2.13 & 0.12 \\
Exch.Ca $\left.(\mathrm{Cmol} \mathrm{kg})^{-1}\right)$ & 1.18 & 0.008 \\
Exch. $\mathrm{Mg}\left(\mathrm{Cmol} \mathrm{kg}^{-1}\right)$ & 0.67 & 0.003 \\
Exch. $\mathrm{K}\left(\mathrm{Cmol} \mathrm{kg}{ }^{-1}\right)$ & 1.03 & 0.011 \\
Exch. $\mathrm{Na}(\mathrm{Cmol} \mathrm{kg}$ & 0.006 \\
\hline
\end{tabular}

N P0-Unamended Soil + 0\% Pollution level; Reported by Idowu and Fayinminnu $(2015 ; 2016)$.

Table 2. Effects of pollution levels and soil amendment on plant heights of kenaf (Hibiscus cannabinus used in phytoremediation

\begin{tabular}{lllllll}
\hline \multirow{2}{*}{ Treatments } & \multicolumn{2}{l}{ Height $(\mathrm{cm})$} & & & \\
& 2WAT & 4WAT & 6WAT & 8WAT & 10WAT & 12 WAT \\
\hline Soil Amendment & & & & & & \\
APS & $7.802^{\mathrm{a}}$ & $14.733^{\mathrm{a}}$ & $20.018^{\mathrm{a}}$ & $39.920^{\mathrm{a}}$ & $85.869^{\mathrm{a}}$ & $96.360^{\mathrm{a}}$ \\
UPS & $7.767^{\mathrm{a}}$ & $8.902^{\mathrm{b}}$ & $12.562^{\mathrm{b}}$ & $18.858^{\mathrm{b}}$ & $41.713^{\mathrm{b}}$ & $59.691^{\mathrm{b}}$ \\
SE \pm & 0.13 & 0.199 & 0.363 & 1.333 & 2.359 & 2.645 \\
Pollution Levels & & & & & & \\
0 & $7.663^{\mathrm{a}}$ & $17.270^{\mathrm{a}}$ & $24.677^{\mathrm{a}}$ & $48.183^{\mathrm{a}}$ & $96.650^{\mathrm{a}}$ & $114.930^{\mathrm{a}}$ \\
3 & $7.840^{\mathrm{a}}$ & $9.120^{\mathrm{b}}$ & $13.003^{\mathrm{b}}$ & $24.783^{\mathrm{b}}$ & $62.180^{\mathrm{b}}$ & $76.410^{\mathrm{b}}$ \\
6 & $7.850^{\mathrm{a}}$ & $9.063^{\mathrm{b}}$ & $11.190^{\mathrm{c}}$ & $15.200^{\mathrm{c}}$ & $32.543^{\mathrm{c}}$ & $42.737^{\mathrm{c}}$ \\
SE \pm & 0.159 & 0.244 & 0.444 & 1.633 & 2.89 & 3.24 \\
\hline
\end{tabular}

Means with the same alphabets are not significantly different at $p<0.05$ level of significance using Duncan Multiple Range Test.

WAT-Weeks After Transplanting. 


\section{Macrothink}

APS-Amended Polluted Soil.

UPS-Unamended Polluted Soil

$\mathrm{SE} \pm-$ Standard Error.

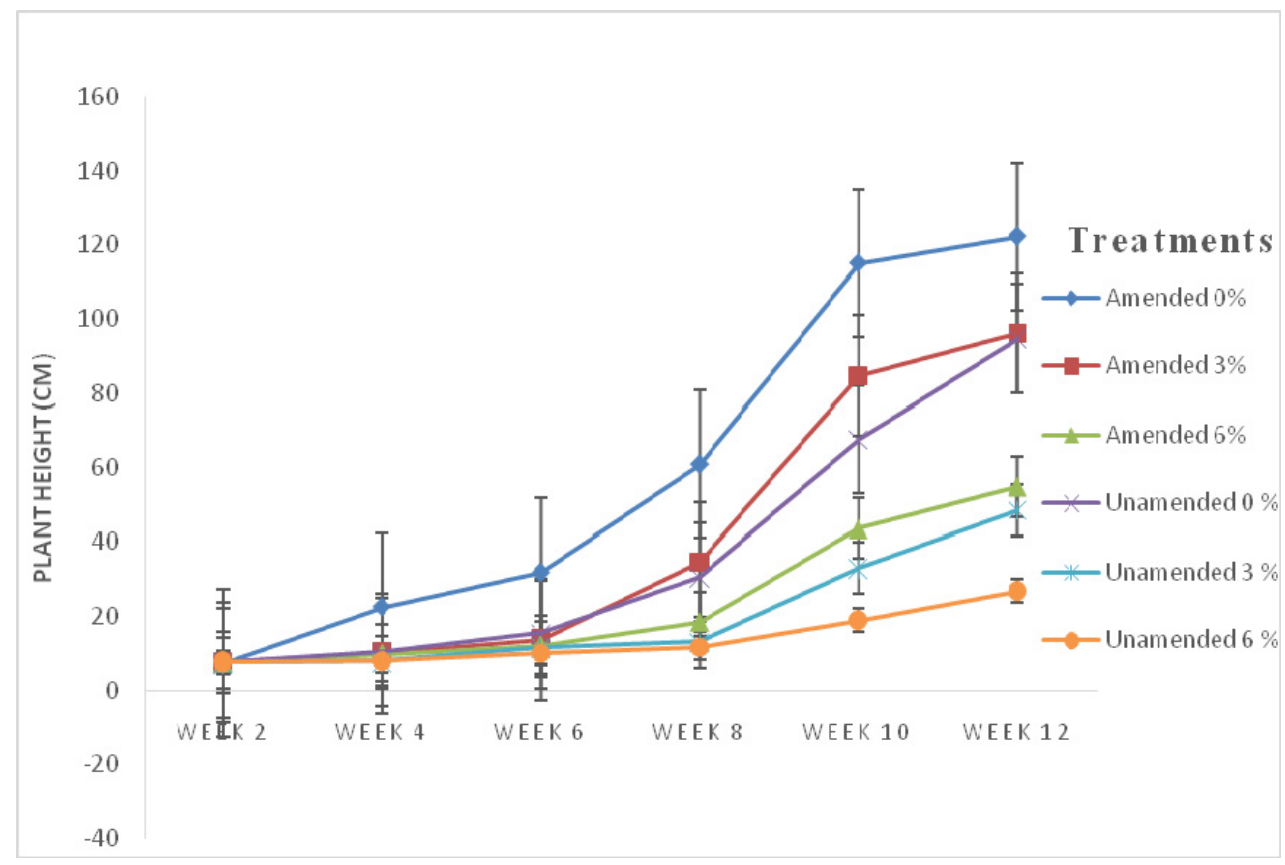

Figure 1. Effects of Spent Lubricating Oil (SLO) pollution levels on plant height of kenaf (Hibiscus cannabinus) grown on amended and unamended soils

\subsubsection{Effects of Levels of Pollution and Soil Amendment on Stem Diameter of H. cannabinus}

The effect of pollution levels and organic amendment on the stem diameter of kenaf $(H$. cannabinus) is shown in Table 3 and Figure 2. Results revealed significant differences $(\mathrm{p}<0.05)$ in stem diameter for amended and unamended soils. The lowest stem diameter value $(0.98 \mathrm{~cm})$ was recorded in the unamended plot at 2WAT, while the highest value of $5.18 \mathrm{~cm}$ was recorded in the amended plot at 12WAT. Significant differences $(\mathrm{p}<0.05)$ were also observed in stem diameter for the different levels of pollution with the exception at 2 WAT where there were no significant differences $(\mathrm{P}>0.05)$ at 3 and $6 \%$ levels of pollution. The lowest values 0.82 and $0.83 \mathrm{~cm}$ of stem diameter were obtained at 2WAT from the pollution level of 3 and $6 \%$, respectively, while the highest stem diameter value of $(7.59 \mathrm{~cm})$ was recorded at $12 \mathrm{WAT}$ from pollution level of $0 \%$. Results at 12 weeks (Figure 2) also showed amended at $0 \%$ pollution (control) having highest mean value $(8.92 \mathrm{~cm})$, followed by unamended $0 \%$ pollution (control) with higher mean value $(6.44 \mathrm{~cm})$ of stem diameter. Soil amended at $3 \%$ pollution had the high mean value $(4.91 \mathrm{~cm})$, while the lowest mean value $(1.62 \mathrm{~cm})$ was recorded from unamended at $6 \%$ pollution. 
Table 3. Effects of pollution levels and soil amendment on stem diameter of H. cannabinus

\begin{tabular}{lllllll}
\hline \multirow{2}{*}{ Treatments } & \multicolumn{5}{c}{ Stem Diameter $(\mathrm{cm})$} \\
& 2WAT & 4WAT & 6WAT & 8 WAT & 10WAT & 12 WAT \\
\hline Soil Amendment & & & & & & \\
APS & $1.219^{\mathrm{a}}$ & $2.483^{\mathrm{a}}$ & $3.395^{\mathrm{a}}$ & $3.975^{\mathrm{a}}$ & $4.628^{\mathrm{a}}$ & $5.175^{\mathrm{a}}$ \\
UPS & $0.978^{\mathrm{b}}$ & $1.258^{\mathrm{b}}$ & $1.471^{\mathrm{b}}$ & $1.851^{\mathrm{b}}$ & $2.292^{\mathrm{b}}$ & $3.296^{\mathrm{b}}$ \\
SE \pm & 0.02 & 0.061 & 0.1 & 0.126 & 0.117 & 0.157 \\
Pollution Levels & & & & & & \\
0 & $1.646^{\mathrm{a}}$ & $3.141^{\mathrm{a}}$ & $3.811^{\mathrm{a}}$ & $4.633^{\mathrm{a}}$ & $5.790^{\mathrm{a}}$ & $7.592^{\mathrm{a}}$ \\
3 & $0.823^{\mathrm{b}}$ & $1.455^{\mathrm{b}}$ & $2.158^{\mathrm{b}}$ & $2.567^{\mathrm{b}}$ & $2.868^{\mathrm{b}}$ & $3.264^{\mathrm{b}}$ \\
6 & $0.826^{\mathrm{b}}$ & $1.017^{\mathrm{c}}$ & $1.331^{\mathrm{c}}$ & $1.539^{\mathrm{c}}$ & $1.721^{\mathrm{c}}$ & $1.851^{\mathrm{c}}$ \\
SE \pm & 0.024 & 0.075 & 0.123 & 0.154 & 0.144 & 0.192 \\
\hline
\end{tabular}

Means with the same alphabets are not significantly different at 5\% level of significance using Duncan Multiple Range Test.

WAT-Weeks after Transplanting.

APS-Amended Polluted Soil.

UPS-Unamended Polluted Soil.

$\mathrm{SE} \pm$-Standard Error.

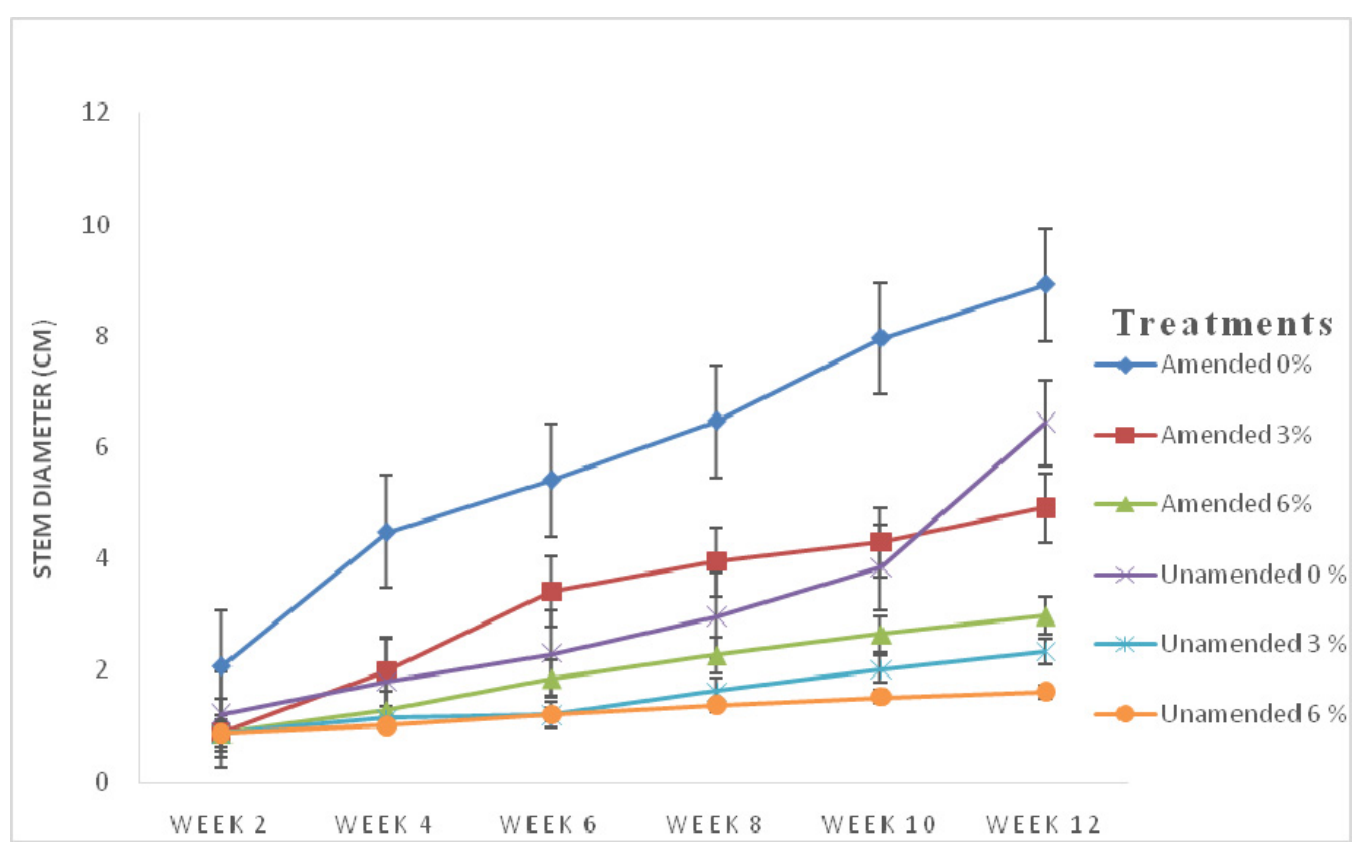

Figure 2. Effects of Spent Lubricating Oil (SLO) pollution levels on Stem diameter of kenaf (Hibiscus cannabinus) grown on amended and unamended soils 
3.2.3 Effects of Levels of Pollution and Soil Amendment on Number of Leaves of $H$. cannabinus

Results presented in Table 4 and Figure 3 showed that, the number of leaves followed almost the same trend for both the soil amendment and the levels of pollution. There were significant differences $(p<0.05)$ in number of leaves recorded in amended and unamended soils except at 2WAT with the lowest value of 3.89 and highest value of 88.93 at 4 and 12WAT, respectively. Significant differences $(\mathrm{p}<0.05)$ in the number of leaves were observed between the control $(0 \%)$ and $3 \%$ levels of pollution as well as 0 and $6 \%$ levels of contamination at 4 and 6 WAT. There were however, no significant differences $(\mathrm{p}>0.05)$ in number of leaves at 3 and $6 \%$ levels of pollution. Results from 6 to 12 WAT revealed significant differences $(p<0.05)$ in number of leaves which existed across the 3 levels of pollution. The lowest number of leaves (2.93) was recorded at 4 WAT from $6 \%$ level of pollution, while the highest number of leaves (139.97) was obtained at 12 WAT from $0 \%$ level of pollution. Highest mean number of leaves was produced from the amended soil at $0 \%$ pollution (control). This was followed by unamended soil at $0 \%$ pollution (control) in producing higher mean value of 85.50 and 59.94 high mean value number of leaves from amended $3 \%$ pollution, while the lowest value $(8.06)$ was recorded from unamended $6 \%$ pollution (Figure 3).

Table 4. Effects of pollution levels and soil amendment on number of leaves of $H$. cannabinus

\begin{tabular}{lcccccc}
\hline \multirow{2}{*}{ Treatments } & \multicolumn{5}{c}{ Number of Leaves } \\
& 2WAT & 4WAT & 6WAT & 8WAT & 10WAT & 12WAT \\
\hline Soil Amendment & & & & & & \\
APS & $5.778^{\mathrm{a}}$ & $9.800^{\mathrm{b}}$ & $15.711^{\mathrm{a}}$ & $40.667^{\mathrm{a}}$ & $64.333^{\mathrm{a}}$ & $88.933^{\mathrm{a}}$ \\
UPS & $5.444^{\mathrm{a}}$ & $3.889^{\mathrm{a}}$ & $5.889^{\mathrm{b}}$ & $9.400^{\mathrm{b}}$ & $20.933^{\mathrm{b}}$ & $37.267^{\mathrm{b}}$ \\
SE \pm & 0.129 & 0.201 & 0.549 & 1.557 & 2.105 & 3.694 \\
Pollution Levels & & & & & & \\
0 & $5.533^{\mathrm{a}}$ & $14.633^{\mathrm{a}}$ & $23.733^{\mathrm{a}}$ & $57.033^{\mathrm{a}}$ & $96.633^{\mathrm{a}}$ & $139.97^{\mathrm{a}}$ \\
3 & $5.700^{\mathrm{a}}$ & $2.967^{\mathrm{b}}$ & $4.600^{\mathrm{b}}$ & $12.567^{\mathrm{b}}$ & $23.667^{\mathrm{b}}$ & $38.37^{\mathrm{b}}$ \\
6 & $5.600^{\mathrm{a}}$ & $2.933^{\mathrm{b}}$ & $4.067^{\mathrm{b}}$ & $5.500^{\mathrm{c}}$ & $7.600^{\mathrm{c}}$ & $10.97^{\mathrm{c}}$ \\
$\mathrm{SE} \pm$ & 0.158 & 0.246 & 0.673 & 1.906 & 2.578 & 4.525 \\
\hline
\end{tabular}

Means with the same alphabets are not significantly different at 5\% level of significance using Duncan Multiple Range Test.

WAT-Weeks after Transplanting.

APS-Amended Polluted Soil.

UPS-Unamended Polluted Soil.

$\mathrm{SE} \pm$-Standard Error. 


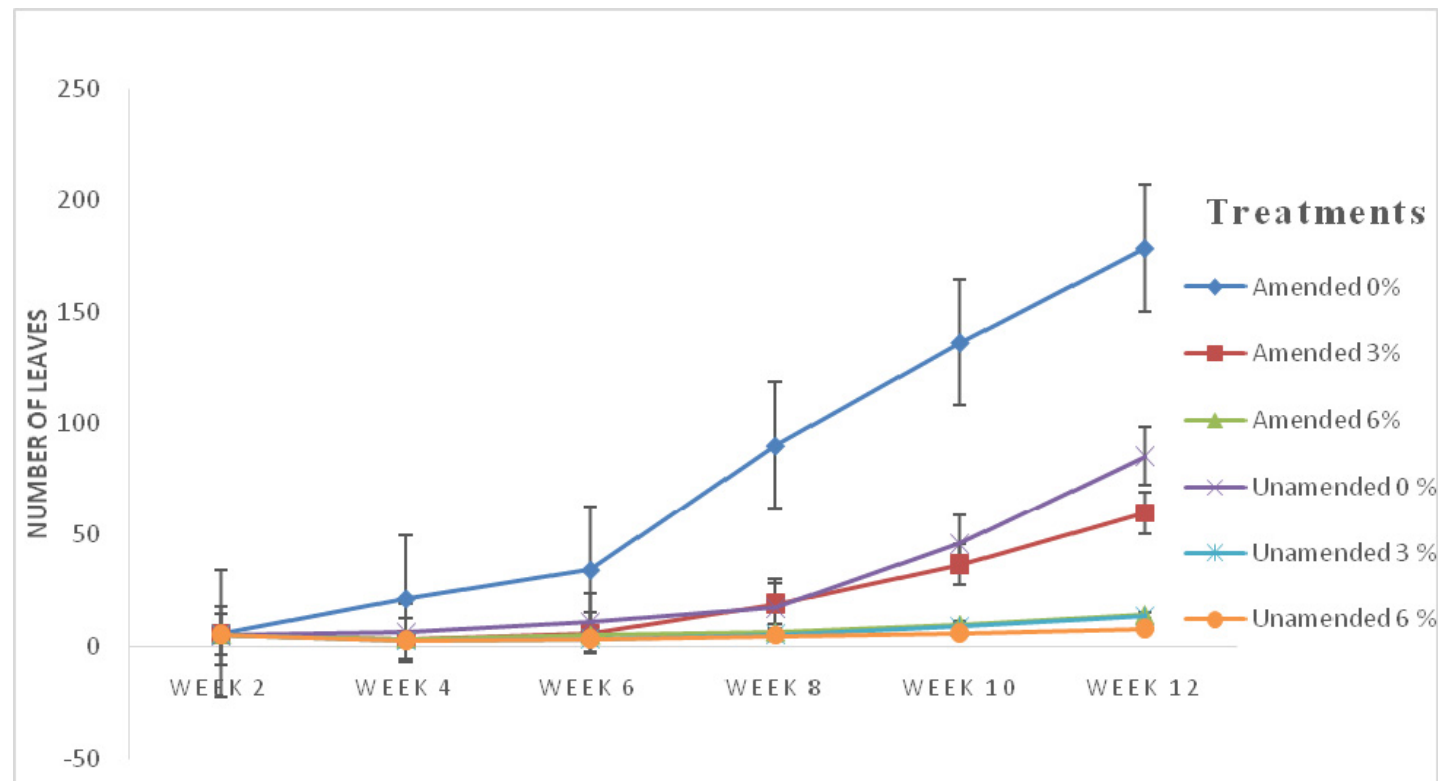

Figure 4. Effects of Spent Lubricating Oil (SLO) pollution levels on Number of leaves of kenaf (Hibiscus cannabinus) grown on amended and unamended soils

\subsection{Total Petroleum Hydrocarbon (TPH) Contents in Phytoremediated Soil}

Results from the Total Petroleum Hydrocarbon (TPH) contents in the phytoremediated soil showed reductions in mean TPH values in all the treatments over every 28 days of assessment in this study (Table 5). There were similar lowest reductions in mean TPH values (2590.00; $2546.00 \mathrm{mg} / \mathrm{kg}$ ) for unamended and amended at $0 \%$ pollution (controls), respectively. This was followed by lower reduction of TPH mean value of $30730.33 \mathrm{mg} / \mathrm{kg}$ from amended $3 \%$ pollution, while the highest TPH value $(46535.00 \mathrm{mg} / \mathrm{kg})$ was recorded from unamended $6 \%$ pollution at 28 days. The same trend in results followed at 56 days when the amended $0 \%$ pollution recorded the least mean value of TPH $(2019.80 \mathrm{mg} / \mathrm{kg})$, followed by unamended $0 \%$ pollution recording $2458.50 \mathrm{mg} / \mathrm{kg}$. Also amended $3 \%$ pollution recorded lower TPH mean value $6150.45 \mathrm{mg} / \mathrm{kg}$, while unamended $6 \%$ pollution had highest mean TPH value (12290.62 $\mathrm{mg} / \mathrm{kg}$ ). At the end of the experiment (Day 84), lowest mean TPH value $1405.24 \mathrm{mg} / \mathrm{kg}$ was obtained from amended $0 \%$ pollution, followed by unamended $0 \%$ with lower mean TPH value $(2019.30 \mathrm{mg} / \mathrm{kg})$. Amended 3\% pollution recorded the low mean value $(4130.24 \mathrm{mg} / \mathrm{kg}) \mathrm{TPH}$, while highest value $(8924.42 \mathrm{mg} / \mathrm{kg})$ was recorded from unamended $6 \%$ pollution.

Table 5. Total Petroleum Hydrocarbon (TPH) Contents of Polluted soil using H. cannabinus (Kenaf) after transplanting

\begin{tabular}{lllll}
\hline \multirow{2}{*}{ Treatments } & \multicolumn{4}{c}{ TPH $(\mathrm{mg} / \mathrm{Kg})$} \\
& Day 1 & Day 28 (4 WAT) & Day 56 (8 WAT) & Day 84 (12 WAT) \\
\hline UPS $_{0}$ & $5531.40 \pm 87.80$ & $2590.00 \pm 100.22$ & $2458.50 \pm 150.00$ & $2019.30 \pm 150.00$ \\
UPS $_{3}$ & $40502.60 \pm 1641.40$ & $36000.20 \pm 650.18$ & $13170.25 \pm 250.89$ & $5225.63 \pm 0.00$ \\
\hline
\end{tabular}




\begin{tabular}{lllll} 
UPS $_{6}$ & $50177.70 \pm 746.30$ & $46535.00 \pm 100.00$ & $12290.62 \pm 50.20$ & $8924.42 \pm 200.62$ \\
APS $_{0}$ & $5829.92 \pm 105.36$ & $2546.15 \pm 100.36$ & $2019.80 \pm 10.54$ & $1405.24 \pm 40.50$ \\
APS $_{3}$ & $41485.50 \pm 1097.50$ & $30730.33 \pm 50.45$ & $6150.45 \pm 50.12$ & $4130.24 \pm 250.39$ \\
APS $_{6}$ & $49738.70 \pm 570.70$ & $39510.00 \pm 10.50$ & $8780.70 \pm 0.00$ & $4830.15 \pm 300.00$ \\
\hline
\end{tabular}

TPH-Total Petroleum Hydrocarbon.

U-Unamended Soil.

A-Amended Soil.

$\mathrm{P}_{0}, \mathrm{P}_{3}$ and $\mathrm{P}_{6-}-0,3$ and $6 \%$ Pollution Levels.

WAT- Weeks After Transplanting.

3.3.1 Percentage (\%) of Biodegradation/ Net Loss and Total Reduction of Total Petroleum Hydrocarbon (TPH) in Polluted soil using H. cannabinus (Kenaf)

The mean TPH values in the treatments revealed percentage reduction biodegradation/net loss $(\%)$ in the study (Table 6 ). At day 28 , amended soil at $3 \%$ pollution recorded higher percentage loss of oil $(25.88 \%)$, while the least value $(7.24 \%)$ was from the unamended soil at $6 \%$ pollution. The amended $0 \%$ pollution (control) recorded the highest mean TPH loss $(56.35 \%)$, closely followed by unamended $0 \%$ pollution (53.20\%). Results from Day 56 revealed amended 3\% pollution having the highest mean TPH loss $(79.99 \%)$, closely followed by amended and unamended $6 \%$ pollution $(77.78 \% ; 73.59 \%)$, respectively, while the lowest mean value $5.02 \%$ was from the unamended $0 \%$ pollution. At the 84 th day (12 weeks) of phytoremediation, the amended soils at 0,3 and 6 levels recorded higher net percentage reduction of TPH mean values $(30.44 ; 32.88$ and $45.09 \%)$ over the unamended $(17.96 ; 60.31$ and 27.40\%). Results presented in Table 7, revealed the total loss of TPH in amended and unamended soils at three levels of pollution at 84 day (12 weeks) of the study. A higher total percentage reduction of TPH was observed in amended soil (75.90, 90.05 and $90.30 \%)$, as compared to unamended $(63.53,87.08$ and $82.20 \%$ ) at 0,3 and 6 levels of pollution, respectively.

Table 6. Net percentage loss of Total Petroleum Hydrocarbons (TPHs) in Polluted soil using $H$. cannabinus (Kenaf) after transplanting

\begin{tabular}{llll}
\hline \multirow{2}{*}{ Treatments } & \multicolumn{2}{c}{ TPH (Biodegradation) \% Loss } & \\
& Day28 & Day 56 & Day 84 \\
\hline UPS $_{0}$ & $53.20 \pm 1.07$ & $5.02 \pm 1.75$ & $17.96 \pm 4.44$ \\
UPS $_{3}$ & $11.02 \pm 1.98$ & $63.42 \pm 0.04$ & $60.31 \pm 0.76$ \\
UPS $_{6}$ & $7.24 \pm 1.18$ & $73.59 \pm 0.05$ & $27.40 \pm 1.34$ \\
APS $_{0}$ & $56.35 \pm 0.94$ & $20.56 \pm 2.72$ & $30.44 \pm 1.65$ \\
\hline
\end{tabular}




\begin{tabular}{llll}
\hline $\mathrm{APS}_{3}$ & $25.88 \pm 1.84$ & $79.99 \pm 0.13$ & $32.88 \pm 3.53$ \\
$\mathrm{APS}_{6}$ & $20.53 \pm 1.74$ & $77.78 \pm 0.01$ & $45.09 \pm 3.51$ \\
\hline
\end{tabular}

TPH-Total Petroleum Hydrocarbon

U-Unamended Soil

A-Amended Soil

$\mathrm{P}_{0}, \mathrm{P}_{3}$ and $\mathrm{P}_{6}-0,3$ and $6 \%$ Pollution Levels.

Table 7. Total Percentage (\%) Reduction (Biodegradation) of TPH in Unamended and Amended soils at pollution levels at day 84 (12 weeks) Phytoremediation

\begin{tabular}{lll}
\hline Treatment & Total TPH $(\%)$ & Loss \\
\hline Unamended Soil & & \\
UPS $_{0}$ & $61.63 \pm 0.24$ & $63.53 \pm 2.13$ \\
UPS $_{3}$ & $87.79 \pm 9.96$ & $87.08 \pm 0.53$ \\
UPS $_{6}$ & $63.16 \pm 0.55$ & $82.22 \pm 0.14$ \\
Amended Soil & & \\
APS $_{0}$ & $76.88 \pm 19.01$ & $75.90 \pm 0.26$ \\
APS $_{3}$ & $85.18 \pm 0.95$ & $90.05 \pm 0.34$ \\
APS $_{6}$ & $82.36 \pm 1.36$ & $90.30 \pm 0.39$ \\
\hline
\end{tabular}

TPH-Total Petroleum Hydrocarbon.

U-Unamended Soil.

A-Amended Soil

$\mathrm{P}_{0}, \mathrm{P}_{3}$ and $\mathrm{P}_{6}-0,3$ and $6 \%$ Pollution Levels.

\section{Discussion}

Phytotoxic effects of Spent Lubricating Oil (SLO) pollution levels were observed on growth parameters (plant height, stem diameter and number of leaves) of kenaf plant in both amended and unamended soils. Although parameters from amended performed better but could not be compared favourably with the control over the period of 84 days (12 weeks) in this study. This could be as a result of reduce in photosynthesis of plant leaves due to coating of roots with spent oil which could have disrupted the architecture, and led to decrease in nutrients uptake by the plants (Khan et al 2013; Pezeshki et al., 2000) and other physiological and biochemical activities. This finding conforms to the earlier study of Idowu and Fayinminnu (2015) on Jatropha curca with significant reduction of growth parameters from SLO polluted soil.

Decreased in plant biomass which could increase plant mortality after oil pollution have also been observed on plants (Merkl et al., 2005a; Yang et al., 2009; Spiares et al., 2001 and Fayinminnu \& Abimbola, 2016). Toxic effects on the growth parameters might have also been 
caused by the presence of high toxic hydrocarbons which could be in form of aliphatic, aromatic and phenolic compounds in the total petroleum hydrocarbons resulting to systemic toxicity on the plant (Trap et al., 2005). Deleterious effects on kenaf plant showed dose dependent whereby pollution at higher level produced reduction in all growth parameters (Sharifi et al., 2007; Idowu \& Fayinminnu, 2015; Fayinminnu \& Abimbola, 2016).

Biodegradation activity of kenaf in reducing Total petroleum hydrocarbons (TPHs) in this study might have been enhanced by the addition of the organic amendment. This is in line with results from Jatropha curca study planted on polluted spent oil with addition of organic amendment as earlier reported by Idowu and Fayinminnu (2016). Abioye et al. (2010) observed that, the addition of different organic wastes into contaminated soil planted with kenaf enhanced biodegradation percentage of oil in the soil. Addition of organic amendment could also have increased the presence of higher microbial population at the rhizosphere of Hibiscus cannabinus plant hence increasing their activities in TPHs degradation. Higher living plants are associated with microorganisms because they create unique habitats on and around their roots where the microbial population is higher in rhizophere than root free soil (unrhizophere) (Lu et al., 2010).

Degradation activity of the kenaf plant could be influenced by the composition of the plant exudates produced (Gleba et al., 1999; Abioye et al., 2010; Spiares et al., 2010) which is readily metabolized by the microorganisms in soil thereby increasing their population. Increment in microbial population enhanced the activity in the rhizosphere which may lead to increase in the metabolic transformation to remediate toxic pollutants to less toxic products (Meagher, 2000; Spiares et al., 2010).

More than 55\% of TPHs were lost through kenaf plant as shown in this phytoremediation study. This is in agreement with the studies carried out by the Mississippi Forest Products Laboratory (MFPL, 1994) and reported by Borazjani and Diehl (1994; 2000) that kenaf (Hibiscus cannabinus) absorbed $55 \%$ of oil from contaminated soil through its many pores with less leakage. The work further revealed that kenaf could also remove pollutants from soil and made them more available to microorganisms (native to kenaf) thereby enhancing pollutants degradation. Centre for Environmental Resources and Sustainable Ecosystems (CERASE, 2002) also used kenaf plant and microorganisms in oil spillage in Nigeria. The report from the project revealed cleanup of oil spills from the environment by kenaf plant. Hibiscus cannabinus might have provided higher population of microorganisms in assisting remediation, hence an effective phytotreatment plant.

\section{Conclusion.}

This study revealed the biodegradation potential of Hibiscus cannabinus (kenaf) plant with organic amendment on Total Petroleum Hydrocarbons with percentage reduction and lower residue at 0,3 and $6 \%$ pollution levels throughout the 84 days (12 weeks) period of study. Kenaf plant however, has proved effective in cleaning spent engine oil polluted soil and as an environmental cleaner; hence it can be used as an enhancer for phytoremediation. 


\section{Acknowledgement}

The author is very grateful and appreciates Mr Damilola Oluyoye Idowu of Forestry Research Institute Nigeria for his assistance during this study. The staff members of Nursery Site of Moist Forest Research Station (FRIN) are appreciated. Also staff members of National Centre for Genetic Resources and Biotechnology (NACGRAB), Moor Plantation, Ibadan, Nigeria are appreciated for providing Kenaf seeds.

\section{References}

Abioye, O. P., Agamuthu, P., \& Abdul, A. A. (2010). Phytoremediation potential of Kenaf (Hibiscus cannabinus) in soil contaminated with used lubricating oil. Linnaeus ECO-TECH 10, 808-816. https://doi.org/10.15626/Eco-Tech.2010.087

Adenipekun, O., Otetungi, O. S., \& Kassim, C. Q. (2008). Effect of spent oil on the growth parameters and chlorophyll content of Corchorus olitorious L. Environmentalist, 28, 446-450. https://doi.org/10.1007/s10669-008-9165-5

Adesodun, J. K., \& Nbagwu, J. S. C. (2008). Biodegradation of waste lubricating petroleum oil in a tropical alfisol as mediated by animal droppings. Bioresource Technology, 99, 5659-5665. https://doi.org/10.1016/j.biortech.2007.10.031

Amakari, J. O., \& Onofeghara, F. A. (1983). Effect of crude oil pollution on the growth of Zea mays, Abelmoschus esculentus and Capsicum frutescens. Oil Petrolchem. Pollut, 13, 199-205. https://doi.org/10.1016/S0143-7127(83)90182-5

AOAC. (2005). Official method of analysis (15th ed., pp. 11-14). Association of Analytical Chemists.Washington DC.

Balogun, M. O., \& Raji, A. O. (2016). Effects of particle size, stem component and genotype on absorbency of Kenaf (Hibiscus cannabinus L.) grown in Nigeria for Oil-Spill Clean-Up. Agricultural Sciences, 7, 621-629. https://doi.org/10.4236/as.2016.79058

Balogun, M. O., Raji, J. A., \& Akande, S. R. (2008). Morphological Diversity of 51 Kenaf Accessions in Nigeria. Revista Cientifica UDO Agricola, 8, 23-28.

Berti, M., Kamireddy, S., \& Ji, Y. (2013). Row spacing affects Biomass yield and composition of kenaf (Hibiscus cannabinus L) as a lignocellulosic feedstock for Bioenergy. Journal of Sustainable Bioenergy Systems, 3(1), 68-73. https://doi.org/10.4236/jsbs.2013. 31009

Borazjani, A., \& Diehl, S. (2010). Kenaf Core as an Enhancer of Bioremediation. Retrieved from http://journey to forever.org/

Borazjani, A., \& Diehl, S. (1994). In C. E. Goforth, \& M. J. Fuller (Eds.), A summary of kenaf production and product development research, biofuel.html 1989-1993.

Centre for Environmental Resources And Sustainable Ecosystems (CERASE). (2002). Focus on environmental remediation in oil region (formerly IRIN News) http://www.thenewhumanitarian.org/feature/2002/01/17/focus-environmental-remediation-oil 
-region-0

Cheng, Z. (2001). Kenaf research products and applications in Japan. Plant fibres and products, 23(3), 16-24.

Dowling, D. N., \& Doty, S. L. (2009). Improving phytoremediation through biotechnology. Current Opinion in Biotechnology, 20, 204-206. https://doi.org/10.1016/j.copbio.2009.03.007

Ebere, J. U., Wokoma, E. C., \& Wokocha, C. C. (2011). Enhanced Remediation of a Hydrocarbon Polluted Soil. Research Journal of Environmental and Earth Sciences, 3(2), 70-74.

Euliss, K., Ho, C., Schwab, A. P., Rock, S., \& Banks, M.K. (2008). Greenhouse and field assessment of phytoremediation for petroleum contaminants in a riparian zone. Bioresource Technology, 99, 1961-1971. https://doi.org/10.1016/j.biortech.2007.03.055

Fayinminnu, O. O., \& Abimbola, M. O. (2016). Assessment of heavy metals and Total Petroleum Hydrocarbons accumulation in Tomato (Solanum lycopersicon L.) grown on Spent Oil polluted soil. Nigerian Journal of Ecology, 15(2), 1-11.

Gileba, D., Borisjuk, N. V., Borisjuk, L. G., Kneer, R., Poulev, A., Skarzhinskaya, M., \& Raskin, I. (1999). Use of plant roots for phytoremediation and molecular farming. Proceeding of the National Academy of Sciences, 96(11), 5973-5977. https://doi.org/10.1073/pnas.96.11. 5973

Haung, X. D., Alawi, Y. E., Penrose, D. M., Glick, B. R., \& Greenberg, B. M. (2004). A multi process phytoremediation system for removal of polycyclic aromatic hydrocarbons from contaminated soils. Environ. Pollut., 130, 465-476. https://doi.org/10.1016/j.envpol.2003. 09.031

Hendershot, W. H., Lanlade, H., \& Duquette, M. (1993). Soil reaction and exchange acidity. In M. R. Carter, (Ed.). Soil sampling and method of analysis (pp. 141-145). Canadian Society of Soil Sciences, Lewis Publishers London.

Hosomi, K. (2000). Utilization dried kenaf leaves to the meal. Proceeding of the 2000 International Kenaf Symposium, Hiroshima, Japan, Oct. 13 -14, 171-176.

Idowu, O. D., \& Fayinminnu, O. O. (2016). Total Petroleum Hydrocarbon and Heavy Metal Remediation with Jatropha curcas L. Seedlings Grown on Spent Oil Polluted Soil. Nature and Science, 14(4), 1-7.

Idowu, O. D., \& Fayinminnu, O. O. (2015). Phytotoxicity effect of spent oil on Jatropha caucus L. seedlings used in soil phytoremediation. Ethiopian Journal of Environmental Studies and Management, 8(2), 906-915. https://doi.org/10.4314/ejesm.v8i2.5S

International Institute of Tropical Agriculture, (I.I.T.A.) (2002). Analytical Procedure for determining soil nutrient Interaction between Plants and Bacteria. Environ. Rev. 6, 65-79.

Khan, S., Afzal, M., Iqbal, S., \& Khan, Q. M. (2013). Plant bacteria partnerships for the remediation of hydrocarbon contaminated soils. Chemosphere, 90(4), 1317-1332. 
https://doi.org/10.1016/j.chemosphere.2012.09.045

Karthikeyan, R., Davis, L. C., Mankin, K. R., Erickson, L. E., \& Kulakow, P. A. (1999). Biodegradation of jet fuel (JP-8) in the presence of vegetation. In: Proceedings of the 1999 conference on hazardous waste research, St. Louis, Missouri.

Lam, T. B. T. (2000). Structured details of kenaf cell walls and fixation of carbon dioxide. Proceedings of the 2000 International Kenaf Symposium, Hiroshima, Japan.

Liu, A. M. (2003). Making pulp and paper from http://www.chinaconsultinginc.com/paperpu

Meagher, R. B. (2000). Phytoremediation of toxic chemical elemental and organic pollutants. Current Opinion in Plant Biology, 3(2), 153-162. https://doi.org/10.1016/S1369-5266(99) 00054-0

Meinz, V. (1999). Used oil characterization study. Washington State department of Ecology solid and hazardous waste program hazardous waste section Olympia, Washington 98504-8711.

Merkl, N., Schultze-Kraft, R., \& Infante, C. (2005a). Phytoremediation in the tropicsinfluence of heavy crude oil on root morphological characteristics of graminoids. Environmental Pollution, 138(1), 86-91. https://doi.org/10.1016/j.envpol.2005.02.023

Mississippi Forest Products Laboratory (MFPL). (1994). Mississippi Agriculture and Forestry Experimental Station Bulletin 1011, Mississippi State University, Mississippi, pp. 26-27.

Nwoko, C. O., Okeke, P. N., \& Chukwuocha, N. (2004). Preliminary studies on nutrients removal potential of selected aquatic plants. J.Discovery and Innovation. Afr. Acad. Sci, 16(3), 133-136. https://doi.org/10.4314/dai.v16i3.15668

Odjegba, V., \& Sadiq, A. O. (2002). Effects of spent engine oil on the growth parameters, chlorophyll and protein levels of Amaranthus hybridus L. The Environmentalist, 22, 23-28. https://doi.org/10.1023/A:1014515924037

Oil of Poverty in the Niger Delta. (2004). A publication by African Network for Environmental and Economic Justice.

Peer, W. A., Baxter, I. R., Richards, E. L., Freeman, J. L., \& Murphy, A. S. (2006). Phytoremediation and Hyperaccumulator Plants. Chap 7 in Molecular Biology of Metal Homeostasis and Detoxification. Springer, Berlin. https://doi.org/10.1007/4735_100

Peng, S., Zhou, Q., Cai, Z., \& Zhang, Z. (2009). Phytoremediation of petroleum contaminated soils by Mirabilis jalapa L. in a greenhouse plot experiment. Journal of Hazardous Materials, 168(2-3), 1490-1496. https://doi.org/10.1016/j.jhazmat.2009.03.036

Pezeshki, S. R., Hester, M. W., Lin, Q., \& Nyman, J. A. (2000). The effects of oil spill and clean-up on dominant US Gulf coast marsh macrophytes: a review. Environmental Pollution, 108(2), 129-139. https://doi.org/10.1016/S0269-7491(99)00244-4

Sameshima, K. (2000). Improvement of Kenaf Core Oil Absorption Property by Heat 


\section{Macrothink}

Treatment at $200^{\circ} \mathrm{C}-500^{\circ} \mathrm{C}$. Proceedings of $3 \mathrm{rd}$ Annual America Kenaf Society Conference, Corpus Christi, 23-25 February 2000, 64-72.

Science in Africa. (2002). Environmental Remediation in Nigerian Oil Regions. Science Magazine for Africa. Available at Africa`s first online Science Magazine.

Sharifi, M., Sadeghi, Y., \& Akbarpour, M. (2007). Germination and growth of six plant species on contaminated soil with spent oil. Int. J. Environ. Sci. Tech., 4(4), 463-470. https://doi.org/10.1007/BF03325982

Spiares, J. D., Kenworthy, K. E., \& Rhykerd, R. L. (2001). Root and Shoot Biomass of plants seeded in crude oil contaminated soil. Texas Journal of Agriculture and Natural Resources, 14, 117-124.

The Nation Newspaper. (2015). Niger Delta Report: Oil spills keep devastating Niger Delta.March. pp. 30-35

Trap, S., Kohler, A., Larsen, L. C., Zambrano, K. C., \& Karlson, U. (2005). Phytotoxicity of fresh and weathered diesel and gasoline to willow and poplar trees. J. Soil Sediments, 1, 71-76. https://doi.org/10.1007/BF02987712

United State Environmental Protection Agency Office of Research and Development (USEPA) (2007). Developing innovative solutions for oil spill cleanup. Land Research Program. Retrieved from http:/www.epa.gov/research/npd/dfs/lrp-factsheet-oil-spills.pdf

Vwioko, D. E., \& Fashemi, D. S. (2005). Growth Response of Ricinus communis L. (Castor Oil) in Spent Lubricating Oil Polluted soil. J. Appl. Sci. Environ. Manage, 9(2), 73-79. https://doi.org/10.4314/jasem.v9i2.17294

Wenzel, W. W. (2009). Rhizosphere processes and management in plant-assisted bioremediation (phytoremediation) of soils. Plant Soil, 321, 38-408. https://doi.org/10.1007/ s11104-008-9686-1

Yang, S. Z., Jin, H. J., Wei, Z., He, R. X., Ji, Y. J., Li, X. M., \& Yu, S. P. (2009). Bioremediation of oil spills in cold environment a review. Pedosphere, 19(3), 371-381. https://doi.org/10.1016/S1002-0160(09)60128-4

\section{Copyrights}

Copyright for this article is retained by the author(s), with first publication rights granted to the journal.

This is an open-access article distributed under the terms and conditions of the Creative Commons Attribution license (http://creativecommons.org/licenses/by/4.0/) 